\title{
KETAHANAN PANGAN: SITUASI, PERMASALAHAN, KEBIJAKAN, DAN PEMBERDAYAAN MASYARAKAT
}

\author{
Yunastiti Purwaningsih \\ Fakultas Ekonomi Universitas Sebelas Maret, Surakarta \\ E mail: yst_stm@yahoo.com
}

\begin{abstract}
The problem of food security is availability, distribution, and consumption. The problem of availability is limited and decreasing production capacity; the distribution's problems are infrastructure, institution, safety link of distribution's and the variation production capacity between region and season. The problem of consumption is most of energy consumption are grain and rice biased. The policy of food security not only to create the food sufficiency with development economic with rural and agriculture are the basis, but also the sufficiency of food for poor society. In order to create food reserve of society, lumbung desa is important to be improved.
\end{abstract}

Key words: food security, rural, agriculture, food reserve

\section{PENDAHULUAN}

Peranan sektor pertanian di Indonesia sangat penting dilihat dari keharusannya memenuhi kebutuhan pangan penduduk yang pada tahun 2005 berjumlah 219,3 juta, dan diprediksikan terus bertambah sebesar 1,25 persen (Nainggolan, 2006:78). Pemerintah harus melaksanakan kebijakan pangan, yaitu menjamin ketahanan pangan yang meliputi pasokan, diversifikasi, keamanan, kelembagaan, dan organisasi pangan. Kebijakan ini diperlukan untuk meningkatkan kemandirian pangan. Pembangunan yang mengabaikan keswadayaan dalam kebutuhan dasar penduduknya, akan menjadi sangat tergantung pada negara lain, dan itu berarti menjadi negara yang tidak berdaulat (Arifin, 2004).

Konsep Malthus yang menyatakan bahwa pertumbuhan pangan bagaikan deret hitung dan pertumbuhan penduduk bagai deret ukur, nampaknya mendapat momen- tumnya sekarang. Bangsa Indonesia dengan pertumbuhan penduduk positif, apabila tidak disertai dengan kenaikan produksi pangan, maka akan berpeluang menghadapi persoalan pemenuhan kebutuhan pangan penduduknya di masa datang. Kebutuhan pangan senantiasa meningkat seiring dengan peningkatan jumlah penduduk. Di sisi pemenuhannya, tidak semua kebutuhan pangan dapat dipenuhi, karena kapasitas produksi dan distribusi pangan semakin terbatas. Hal ini menyebabkan ketidakstabilan pangan antara kebutuhan dan pemenuhannya secara nasional.

Dengan demikian pemenuhan kebutuhan pangan ini menjadi sangat penting dan strategis dalam rangka mempertahankan kedaulatan negara, melalui tidak tergantung pada impor pangan dari negara maju. Ketergantungan suatu negara akan impor pangan (apalagi dari negara maju), akan mengakibat- 
kan pengambilan keputusan atas segala aspek kehidupan menjadi tidak bebas atau tidak merdeka, dan karenanya negara menjadi tidak berdaulat secara penuh (Arifin, 2004).

Konsep pangan menurut Undang-undang Nomor 7 tahun 1996 adalah segala sesuatu yang berasal dari hayati dan air, baik yang diolah maupun yang tidak diolah, yang diperuntukkan sebagai makanan dan minuman yang dikonsumsi manusia, termasuk bahan tambahan pangan, bahan baku pangan, dan bahan lain yang digunakan dalam proses penyiapan, pengolahan dan atau pembuatan makanan atau minuman.

Konsep ketahanan pangan menurut Undang-undang Nomor 7 tahun 1996 adalah kondisi terpenuhinya pangan bagi rumah tangga yang tercermin dari tersedianya pangan yang cukup, baik jumlah maupun mutunya, aman, merata, dan terjangkau. Berdasar konsep tersebut, maka terdapat beberapa prinsip yang terkait, baik langsung maupun tidak langsung terhadap ketahanan pangan (food security), yang harus diperhatikan (Sumardjo, 2006):

- Rumah tangga sebagai unit perhatian terpenting pemenuhan kebutuhan pangan nasional maupun komunitas dan individu.

- Kewajiban negara untuk menjamin hak atas pangan setiap warganya yang terhimpun dalam satuan masyarakat terkecil untuk mendapatkan pangan bagi keberlangsungan hidup.

- Ketersediaan pangan mencakup aspek ketercukupan jumlah pangan (food sufficiency) dan terjamin mutunya (food quality).

- Produksi pangan yang sangat menentukan jumlah pangan sebagai kegiatan atau proses menghasilkan, menyiapkan, mengolah, membuat, mengawetkan, mengemas, mengemas kembali dan atau mengubah bentuk pangan.

- Mutu pangan yang nilainya ditentukan atas dasar kriteria keamanan pangan, kandungan gizi dan standar perdagangan terhadap bahan makanan dan minuman.

- Keamanan pangan (food safety) adalah kondisi dan upaya yang diperlukan untuk mencegah pangan dari kemungkinan cemaran biologis, kimia dan benda lain yang dapat menganggu, merugikan dan membahayakan keadaan manusia.

- Kemerataan pangan merupakan dimensi penting keadilan pangan bagi masyarakat yang ukurannya sangat ditentukan oleh derajat kemampuan negara dalam menjamin hak pangan warga negara melalui sistem distribusi produksi pangan yang dikembangkannya. Prinsip kemerataan pangan mengamanatkan sistem pangan nasional harus mampu menjamin hak pangan bagi setiap rumah tangga tanpa terkecuali.

- Keterjangkauan pangan mempresentasikan kesamaan derajat keleluasaan akses dan kontrol yang dimiliki oleh setiap rumah tangga dalam memenuhi hak pangan mereka. Prinsip ini merupakan salah satu dimensi keadilan pangan yang penting untuk diperhatikan.

Konsep ketahanan pangan seperti disebut di atas, selanjutnya dapat diringkas kedalam aspek:

- Ketersediaan pangan: ketercukupan jumlah pangan (food sufficiency).

- Keamanan pangan (food safety): pangan yang bebas dari kemungkinan cemaran biologis, kimia dan benda lain yang dapat 
menganggu, merugikan dan membahayakan keadaan manusia, serta terjamin mutunya (food quality) yaitu memenuhi kandungan gizi dan standar perdagangan terhadap bahan makanan dan minuman.

- Kemerataan pangan: sistem distribusi pangan yang mendukung tersedianya pangan setiap saat dan merata.

- Keterjangkauan pangan: kemudahan rumah tangga untuk memperoleh pangan dengan harga yang terjangkau.

\section{PEMBAHASAN}

\section{Situasi Pangan}

\section{Ketersediaan pangan}

Negara berkewajiban untuk menjamin ketersediaan pangan dalam jumlah yang cukup (selain terjamin mutunya) bagi setiap warga negara, karena pada dasarnya setiap warga negara berhak atas pangan bagi keberlangsungan hidupnya. Penyediaan pangan oleh negara harus diupayakan melalui produksi pangan dalam negeri, dimana produksi ini harus senantiasa meningkat dari tahun ke tahun seiring dengan pertambahan penduduk.

Sebagai penyedia bahan pangan, perjalanan sektor pertanian di Indonesia semenjak 1967 sampai sekarang, secara umum mengalami lima fase: fase konsolidasi, fase tumbuh tinggi, fase dekonstruksi, fase krisis, fase transisi dan desentralisasi (Arifin, 2004). Kinerja ekonomi pertanian selama kurun waktu tersebut, menunjukkan pertumbuhan tanaman pangan yang terus menurun setelah tahun 1986. Ini berarti ketersediaan pangan secara otomatis juga mengalami tren yang menurun. Kinerja selengkapnya pada setiap fase disarikan dalam Tabel 1.

Berdasar pada data Tabel 1 tersebut, apabila diurai setiap fase sebagai berikut (Arifin, 2004):

a. Pada fase konsolidasi 1967-1978, tanaman pangan tumbuh dengan 3,58 persen. Tiga kebijakan yang diterapkan pemerintah pada fase ini dalam membangun pertanian yaitu melalui intensifikasi, ekstensifikasi dan diversifikasi.

- Intensifikasi menunjuk pada penggunaan teknologi biologi dan kimia (pupuk, benih unggul, pestisida, dan hibrisida), serta teknologi mekanis (traktorisasi dan kombinasi mana-

Tabel 1. Pertumbuhan PDB dan Produksi Pertanian Indonesia 1967- 2001

\begin{tabular}{lcccc}
\hline \multicolumn{1}{c}{ Keterangan } & $\begin{array}{c}\text { Konsolidasi } \\
\mathbf{1 9 6 7 - 7 8}\end{array}$ & $\begin{array}{c}\text { Tumbuh Tinggi } \\
\mathbf{1 9 7 8 - 8 6}\end{array}$ & $\begin{array}{c}\text { Dekonstruksi } \\
\mathbf{1 9 8 6 - 9 7}\end{array}$ & $\begin{array}{c}\text { Krisis Ekonomi } \\
\mathbf{1 9 9 7 - 2 0 0 1}\end{array}$ \\
\hline PDB Pertanian & 3,39 & 5,72 & 3,38 & 1,57 \\
- Tanaman Pangan & $\mathbf{3 , 5 8}$ & $\mathbf{4 , 9 5}$ & $\mathbf{1 , 9 0}$ & $\mathbf{1 , 6 2}$ \\
- Tanaman Perkebunan & 4,53 & 5,85 & 6,23 & 1,29 \\
- Peternakan & 2,02 & 6,99 & 5,78 & $-1,92$ \\
- Perikanan & 3,44 & 5,15 & 5,36 & 5,45 \\
Produksi Pertanian & 3,57 & $\mathbf{6 , 7 6}$ & 3,99 & $-\mathbf{0 , 4 7}$ \\
- Produktivitas Lahan & 2,08 & 4,13 & 1,83 & $-1,45$ \\
- Produktivitas Tenaga Kerja & 2,32 & 5,57 & 2,03 & $-0,47$ \\
\hline
\end{tabular}

Sumber: dihitung dari data BPS dan FAO (2003), dalam Arifin (2004:5). 
jemen air irigasi serta drainase).

- Ekstensifikasi adalah perluasan areal yang mengkonversi hutan tidak produktif menjadi areal persawahan dan pertanian.

- Diversifikasi adalah penganekaragaman usaha pertanian untuk menambah pendapatan rumah tangga petani, usaha tani terpadu peternakan, dan perikanan.

Pada saat yang bersamaan pemerintah juga melakukan kebijakan:

- Membangun sarana irigasi, jalan dan industri pendukung (semen, pupuk dan lain-lain).

- Melakukan pembenahan institusi ekonomi seperti konsolidasi kelompok tani hamparan, KUD dan koperasi pertanian lainnya, sistem penyuluhan dengan program andalannya adalah latihan dan kunjungan ke petani.

- Melakukan terobosan skema pendanaan, memberikan kredit pertanian (walau bersubsidi), serta keterjangkauan akses finansial sampai ke tingkat pelosok pedesaan. Ini merupakan reformasi spektakuler di bidang ekonomi.

b. Pada fase tumbuh tinggi periode tahun 1978-1986, tanaman pangan tumbuh dengan 4,95 persen, dimana pada masa ini penerapan revolusi hijau membawa Indonesia kepada pencapaian swasembada pangan pada tahun 1984. Kontribusi riset atau ilmu pengetahuan dan teknologi dalam sektor pertanian menjadikan kinerja produksi pertanian meningkat. Revolusi teknologi menjadi salah satu indikasi tingkat pemerataan di tingkat pedesaan, daerah produksi padi identik dengan kesejahteraan pedesaan. Kinerja yang baik dari institusi ekonomi di tingkat desa, kelompok tani, koperasi pedesaan, sistem penyuluhan, dukungan skema pendanaan dan sistem perbankan, kesemuanya menghasilkan kinerja yang baik pada produksi pertanian. Manajemen pemerintahan Presiden Suharto dengan sistem linier dan komando sangat efektif untuk menjalankan administrasi pemerintahan sampai ke tingkat pedesaan. Sebagai contoh, kebijakan harga dasar gabah dan manajemen operasi pasar untuk menjaga stabilitas harga pangan, berjalan efektif karena persyaratan detil implementasi kebijakan sudah dipersiapkan, mulai pergudangan, armada transportasi, dukungan kredit perbankan sampai pada waktu pengumuman harga dasar baru. Antisipasi harga beras di pasar dunia juga diperhatikan secara seksama.

c. Pada fase dekonstruksi periode tahun 1986-1997, tanaman pangan hanya tumbuh 1,90 persen. Fase ini dinamakan dekonstruksi karena sektor pertanian mengalami fase pengacuhan (ignorance) oleh para perumus kebijakan dan bahkan para ekonom sendiri. Pencapaian swasembada pangan menimbulkan persepsi bahwa pembangunan pertanian akan bergulir dengan sendirinya, sehingga melupakan prasyarat keberpihakan serta kerja keras pada periode sebelumnya. Indikasi fase buruk ini sebenarnya muncul pada tahun 1990-an ketika kebijakan pembangunan ekonomi mengarah ke strategi industrialisasi, dimana berbagai komponen proteksi 
diberikan ke sektor industri, sehingga pertumbuhan sektor industri meningkat pesat, sampai menimbulkan anggapan bahwa proses transformasi struktur ekonomi (dari negara agraris menjadi negara industri) telah berhasil. Upaya proteksi ke sektor industri dilakukan secara sistematis sehingga melumpuhkan basis pertanian di tingkat petani pedesaan, yang pada akhirnya menimbulkan ketidakmerataan pembangunan antara pedesaan dan perkotaan, bahkan juga antara pulau Jawa dan luar Jawa.

d. Pada fase krisis ekonomi periode tahun 1997-2001, tanaman pangan hanya tumbuh 1,62 persen. Pada masa ini yang berawal tahun 1997, terjadi krisis ekonomi yang dipicu oleh krisis nilai tukar dan perbankan, yang kemudian berdampak pada semua sendi perekonomian (inflasi meningkat, pengangguran bertambah sebagai akibat dari pemutusan hubungan kerja), yang selanjutnya menjalar kepada sistem politik. Sektor pertanian harus menanggung dampak krisis ekonomi melalui keharusan menyerap limpahan tenaga kerja sektor informal perkotaan. Dampaknya adalah sektor pertanian termasuk petani, terus terpojok dan terpinggirkan:

- Infrastruktur penting seperti bendungan dan irigasi tidak diurus, baik oleh pemerintah pusat ataupun pemerintah daerah, sehingga pada musim kemarau petani harus menanggung penderitaan paling parah.

- Jalan rusak parah, sehingga mengganggu sistem distribusi komoditas strategis, dan ini meningkatkan biaya transportasi secara signifikan. Harga jual di tingkat konsumen naik sementara harga di tingkat petani tetap, sehingga membuat tidak cukup insentif bagi petani untuk meningkatkan produksi dan produktivitasnya.

e. Pada fase 2001 sampai sekarang merupakan fase transisi politik dan periode desentralisasi. Pembangunan pertanian perlu diterjemahkan menjadi peningkatan basis kemandirian daerah yang secara teoritis dan empiris mampu mengalirkan dan bahkan menciptakan dampak ganda aktivitas lain di daerah. Otonomi daerah perlu diterjemahkan sebagai suatu kewenangan daerah untuk lebih leluasa melakukan kombinasi strategi kompetitif yang ada di suatu daerah otonom, khususnya dalam kerangka pembangunan pertanian dan sektor ekonomi lain pada umumnya.

Produksi pangan sangat tergantung pada tingkat produktivitas dan luas areal panen. Komoditi pangan beras, berdasar data pada Tabel 2 memperlihatkan bahwa luas panen dan produktivitas berfluktuasi selama 19902003, namun fluktuasinya kecil (tidak signifikan), sehingga dapat dinyatakan bahwa angkanya relatif tetap. Selanjutnya dengan data yang sama, impor beras berfluktuasi, dan mencapai puncaknya pada tahun 1998 .

Berdasar data pada Tabel 2, dapat dinyatakan bahwa Indonesia kemungkinan tidak dapat mencapai swasembada beras lagi, apalagi bila dikaitkan dengan kondisi sekarang dimana konversi lahan terjadi terus menerus, utamanya di Jawa, dari pertanian sawah teknis ke pengguna lahan non pertanian, di antaranya digunakan untuk 
Tabel 2. Luas Panen, Produksi, Produktivitas, dan Impor Beras 1990-2003

\begin{tabular}{cccccr}
\hline Tahun & $\begin{array}{c}\text { Luas Panen } \\
\text { (000 ha) }\end{array}$ & $\begin{array}{c}\text { Produktivitas } \\
\text { (ton/ha) }\end{array}$ & $\begin{array}{c}\text { Produksi Gabah } \\
\text { (000 ton) }\end{array}$ & $\begin{array}{c}\text { Produksi Beras } \\
\text { (000 ton) }\end{array}$ & $\begin{array}{c}\text { Impor Beras }^{\mathbf{b}} \\
\text { (000 ton) }\end{array}$ \\
\hline 1990 & 10,502 & 4,30 & 45,179 & 29,366 & 29,000 \\
1991 & 10,282 & 4,35 & 44,689 & 29,048 & 178,000 \\
1992 & 11,103 & 4,34 & 48,240 & 31,356 & 634,000 \\
1993 & 11,013 & 4,38 & 48,181 & 31,318 & 0,000 \\
1994 & 10,734 & 4,35 & 46,641 & 30,317 & 876,000 \\
1995 & 11,439 & 4,35 & 49,744 & 32,334 & 3,014 \\
1996 & 11,569 & 4,41 & 51,101 & 33,215 & 1,090 \\
1997 & 11,141 & 4,43 & 49,377 & 32,095 & 406,000 \\
1998 & 11,613 & 4,17 & 48,472 & 30,537 & 5,765 \\
1999 & 11,963 & 4,25 & 50,866 & 31,118 & 4,183 \\
2000 & 11,793 & 4,40 & 51,898 & 32,345 & 1,513 \\
2001 & 11,415 & 4,39 & 50,181 & 31,283 & 1,400 \\
2002 & 11,521 & 4,47 & 51,379 & 32,369 & 3,100 \\
$2003^{c}$ & 11,453 & 4,53 & 51,849 & 32,697 & 2,000 \\
\hline
\end{tabular}

Tabel Catatan:

a Faktor konversi 0,68 sebelum tahun 1989, dan 0,65 setela tahun 1989, lalu menurun menjadi 0,63 setelah tahun 1998 .

b Data impor beras dikumpulkan dari berbagai sumber.

c Angka ramalan III, Oktober 2003.

Sumber: BPS berbagai tahun, dalam Arifin, 2004, halaman 46, tabel 4.1.

Tabel 3. Produksi Tanaman Pangan 1990-2005 (ribu ton)

\begin{tabular}{lrrrrrrrrr}
\hline Komoditi & $\mathbf{1 9 9 0}$ & $\mathbf{1 9 9 5}$ & $\mathbf{1 9 9 8}$ & $\mathbf{2 0 0 0}$ & $\mathbf{2 0 0 1}$ & $\mathbf{2 0 0 2}$ & $\mathbf{2 0 0 3}$ & $\mathbf{2 0 0 4}$ & $\mathbf{2 0 0 5}$ \\
\hline Padi & $\mathbf{2 0 , 1 7 9}$ & 49,744 & $\mathbf{4 9 , 2 0 0}$ & $\mathbf{5 1 , 8 9 8}$ & $\mathbf{5 0 , 4 6 1}$ & 51,490 & 52,138 & 54,088 & 53,985 \\
Jagung & 6,734 & 8,246 & 10,169 & 9,677 & 9,347 & 9,654 & 10,886 & 11,225 & 12,014 \\
Ubi Kayu & 15,830 & 15,410 & 14,696 & 16,089 & 17,055 & 16,913 & 18,524 & 19,425 & 19,459 \\
Kedelai & 1,487 & 1,680 & 1,306 & 1,018 & 827,000 & 673,000 & 672,000 & 723,000 & 797,000 \\
\hline
\end{tabular}

Sumber:

- Tahun 1990-1998 dari BPS (2003), World Bank (2003), dalam Arifin, 2004, hal.164, tabel 12.1, diolah.

- Tahun 2000-2005 dari Statistik Pertanian 1999-2003, Ditjen Teknis Lingkup Deptan 2004-2005, dalam Nainggolan, 2007, halaman 92 , tabel 1 , diolah.

perumahan, industri, dan sarana-prasarana. Pengalihan fungsi lahan dari fungsi pertanian ke fungsi bangunan menjadi penyebab utama berkurangnya lahan pertanian, yang selanjutnya berdampak pada berkurangnya produksi produk pertanian, terutama pangan. Sementara itu jumlah penduduk masih meningkat, karena pertumbuhannya positip (1,25 persen). Faktor penyebab lain adalah adanya perubahan iklim global yang mengakibatkan bencana alam, sehingga banyak areal panen menjadi puso, dan produksi menghadapi resiko berupa ketidakpastian iklim.

Produksi tanaman pangan selain beras, yaitu jagung dan ubi kayu menunjukkan tren yang meningkat dari tahun 1990-2005, namun untuk kedelai menurun setelah tahun 
Tabel 4. Produksi Kedelai 2005-2007 (ribu ton)

\begin{tabular}{lrrr}
\hline Komoditi & \multicolumn{1}{c}{$\mathbf{2 0 0 5}$} & \multicolumn{1}{c}{$\mathbf{2 0 0 6}$} & $\mathbf{2 0 0 7}$ \\
\hline Sumatera & 67,027 & 50,346 & 43,190 \\
Jawa & $\mathbf{5 6 3 , 2 2 5}$ & $\mathbf{5 1 8 , 4 2 5}$ & $\mathbf{4 2 7 , 3 5 4}$ \\
Bali dan NTT & 120,095 & 122,270 & 76,977 \\
Kalimantan & 7,322 & 7,331 & 5,551 \\
Sulawesi & 41,289 & 40,533 & 37,390 \\
Maluku dan Papua & 9,395 & 8,706 & 7,567 \\
Luar Jawa & $\mathbf{2 4 5 , 1 2 8}$ & $\mathbf{2 2 9 , 1 8 6}$ & $\mathbf{1 7 0 , 6 7 5}$ \\
\hline
\end{tabular}

Sumber: Departemen Pertanian, dalam Kompas, 16 Januari 2008, diolah.

2000, dan meningkat mulai tahun 2004, nampak dalam Tabel 3.

Khusus produksi kedelai tahun 20052007, pulau Jawa merupakan produsen kedelai terbanyak dibanding dengan pulau lain, dimana pada tahun 2007 sebanyak 427,354 ribu ton sedangkan luar Jawa sebanyak 170,675 ribu ton, nampak dalam Tabel 4.

\section{Kemandirian Pangan}

Kemandirian suatu negara dalam memenuhi kebutuhan rakyatnya merupakan indikator penting yang harus diperhatikan, karena negara yang berdaulat penuh adalah yang tidak tergantung (dalam bidang politik, keamanan, ekonomi, dan sebagainya) pada negara lain. Ketergantungan suatu negara dalam memenuhi kebutuhan rakyatnya dapat berbentuk ketergantungan dalam pasokan, pengambilan keputusan, teknologi, atau pola konsumsi, dan gaya hidup. Indonesia dengan penduduk lebih dari 210 juta orang, menjadi sangat berbahaya apabila tidak mandiri dalam pangan. Namun perlu dicatat bahwa kemandirian pangan, tidak berarti menolak ekspor-impor pangan, karena perdagangan internasional yang menguntungkan dapat digunakan untuk mensejahterakan rakyat.

Kemandirian pangan dilihat dari rata-rata pangsa produksi terhadap konsumsi domestik, menunjukkan bahwa sebenarnya peningkatan produksi pangan di Indonesia tidak mampu memenuhi permintaan yang terus meningkat dan bervariasi. Berdasar data neraca bahan pangan FAO tahun 2003, rasio produksi domestik terhadap konsumsi bahan pangan Indonesia tahun 1970-2001 terlihat pada Tabel 5, semua di bawah 100 persen, kecuali ikan (Arifin, 2004:48). Untuk beras, rasionya adalah 95,5 persen, jagung 98,5 persen, kedelai 76,20 dan gula 84,67 persen, yang berarti kekurangan dari 100 persen merupakan impor. Komoditi susu menunjukkan rasio tertinggi 43,66 persen, yang berarti bahwa 57,34 persen konsumsi susu domestik dicukupi dengan impor.

Selanjutnya dengan melihat Tabel 6 nampak bahwa data mengenai porsi beberapa produk pangan terhadap pemenuhan kebutuhan tahun 1995-2005, menunjukkan gula dan susu merupakan produk dengan tingkat kemandirian yang rendah, bahkan dapat dikategorikan pada tahap ketergantungan. Begitu pula untuk gandum dan kedelai 
Tabel 5. Rata-rata Pangsa Produksi terhadap Konsumsi Domestik Pangan Utama Tahun 1970-2001 (dalam persen)

\begin{tabular}{lccc}
\hline $\begin{array}{c}\text { Pangan } \\
\text { Utama }\end{array}$ & $\begin{array}{c}\text { Pertumbuhan } \\
\text { Produksi } \\
\text { per tahun }\end{array}$ & $\begin{array}{c}\text { Pertumbuhan } \\
\text { Konsumsi } \\
\text { per tahun }\end{array}$ & $\begin{array}{c}\text { Rata-rata Pangsa } \\
\text { Produksi terhadap } \\
\text { Konsumsi Domestik }\end{array}$ \\
\hline Beras & 3,14 & 2,96 & 95,50 \\
Jagung & 3,94 & 4,63 & 98,52 \\
Kedelai & 1,65 & 4,55 & 76,20 \\
Gula & 1,35 & 2,53 & 84,67 \\
Daging Sapi & 2,04 & 2,20 & 98,18 \\
Daging Ayam & 8,83 & 8,83 & 99,79 \\
Susu & 5,02 & 4,29 & 43,66 \\
Telur & 7,89 & 7,85 & 99,93 \\
Ikan & 4,52 & 4,34 & 100,75 \\
\hline
\end{tabular}

Sumber: Dihitung dari Neraca Pangan FAO, 2003. dalam Arifin, 2006, halaman 49, tabel 4.2.

Tabel 6. Porsi Beberapa Produk Pangan terhadap Pemenuhan Kebutuhan Total Tahun 1995 - 2005 (dalam persen)

\begin{tabular}{lccc}
\hline \multicolumn{1}{c}{ Komoditi } & $\mathbf{1 9 9 5}$ & $\mathbf{1 9 9 8}$ & $\mathbf{2 0 0 5}$ \\
\hline Beras & $-8,9$ & $-8,3$ & $-0,6$ \\
Jagung & $-11,1$ & $-3,3$ & $-9,8$ \\
Pemanis (Gula) & $-20,1$ & $-32,1$ & $-43,5$ \\
Sayuran & $-2,2$ & $-3,9$ & $-5,1$ \\
Buah & $-1,6$ & $-1,4$ & $-5,2$ \\
Sapi & $-2,2$ & $-2,9$ & $-9,8$ \\
Unggas & $-0,2$ & $-0,1$ & $-2,4$ \\
Susu & $-54,7$ & $-42,5$ & $-81,4$ \\
Telur & $-0,1$ & $-0,1$ & $-1,2$ \\
\hline
\end{tabular}

Sumber: FAO, Food Balance Sheet, beberapa tahun penerbitan, dalam Krisnamurthi. 2006, hal. 35 , tabel 3 .

yang tidak dapat ditampilkan karena perbedaan spesifikasi (digit) data produk (Krisnamurthi, 2006).

Kondisi tersebut membawa Indonesia tergantung pada impor pangan, dan karenanya sangat tergantung pada harga produk tersebut di pasar internasional. Dengan demikian dikaitkan dengan ketersediaan pangan bagi masyarakat, maka apabila terjadi kenaikan harga pangan di pasar internasional, pangan cenderung menjadi barang mewah bagi masyarakat, terutama masyarakat berpendapatan tetap dan masyarakat miskin. Bagi masyarakat pedesaan yang merupakan petani penghasil produksi pangan, kenaikan harga pangan di pasar internasional yang selanjutnya membawa kenaikan harga tersebut di dalam negeri, merupakan insentif bagi petani untuk menanam tanaman pangan tersebut.

\section{Keterjangkauan Pangan}

Keterjangkauan pangan atau aksesibilitas masyarakat (rumah tangga) terhadap bahan 
pangan sangat ditentukan oleh daya beli, dan daya beli ini ditentukan oleh besarnya pendapatan dan harga komoditas pangan. Pengaruh pendapatan terhadap akses pangan dapat dilihat melalui pengeluaran bahan pangan, yaitu dengan besarnya proporsi pengeluaran rumah tangga untuk bahan pangan. Selanjutnya harga pangan berpengaruh terhadap aksesibilitas terhadap bahan pangan melalui daya beli.

a. Pengeluaran Bahan Pangan

Terdapat hubungan yang negatif antara proporsi pengeluaran bahan pangan dan ketahanan pangan (ditinjau dari akses ke pangan) (Hukum Working 1943, dikutip oleh Pakpahan, dkk., 1993 dalam Rachman, dkk., 2002):

- Semakin besar proporsi pengeluaran rumah tangga untuk bahan pangan, maka akses terhadap bahan pangan adalah rendah. Semakin besar proporsi pengeluaran rumah tangga untuk bahan pangan juga menunjukkan rendahnya kepemilikan bentuk kekayaan lain yang dapat ditukarkan dengan bahan pangan.

- Semakin kecil proporsi pengeluaran rumah tangga untuk bahan pangan, maka akses terhadap bahan pangan adalah besar, atau menunjukkan semakin tinggi ketahanan pangannya.

- Semakin kecil proporsi pengeluaran rumah tangga untuk bahan pangan, juga menunjukkan tingginya kepemilikan bentuk kekayaan lain yang dapat ditukarkan dengan bahan pangan.

Ketahanan pangan rumah tangga juga dapat dilihat dari pendapatan rumah tangga dan konsumsi gizi rumah tangga (Johnson dan Toole, 1999), diadopsi oleh
Maxwell et al., 2000 (Rachman, dkk.) sebagai berikut:

- Rumah tangga tahan pangan yaitu bila proporsi pengeluaran pangan rendah (kurang dari 60 persen dari pengeluaran rumah tangga) dan cukup mengkonsumsi energi ( $>80$ persen dari syarat kecukupan energi).

- Rumah tangga rentan pangan yaitu bila proporsi pengeluaran pangan tinggi (lebih dari 60 persen dari pengeluaran rumah tangga) dan cukup mengkonsumsi energi ( $>80$ persen dari syarat kecukupan energi).

- Rumah tangga kurang pangan yaitu bila proporsi pengeluaran pangan tinggi (lebih dari 60 persen dari pengeluaran rumah tangga) dan kurang mengkonsumsi energi ( $\leq 80$ persen dari syarat kecukupan energi).

- Rumah tangga rawan pangan yaitu bila proporsi pengeluaran pangan tinggi dan tingkat konsumsi energinya kurang. (Milifpk, 2007)

Dengan menggunakan indikator proporsi pengeluaran rumah tangga untuk bahan pangan, maka dari tahun 1984-1993 rumah tangga pedesaan mempunyai proporsi pengeluaran rumah tangga untuk makanan yang lebih tinggi dibanding dengan rumah tangga perkotaan. Selama kurun waktu tersebut, lebih dari 60 persen pengeluaran rumah tangga pedesaan digunakan untuk makanan, sedangkan di perkotaan sekitar 50 persen, lihat Tabel 7. Berdasar indikator Johnson dan Toole (1999), yang dilihat dari proporsi pengeluaran untuk pangan, berarti rumah tangga pedesaan adalah rentan terhadap pangan. Ini berarti rumah tangga pedesaan 
Tabel 7. Pengeluaran Rata-rata per Bulan/Kapita Tahun 1984-1993 Menurut Harga Berlaku

\begin{tabular}{|c|c|c|c|c|c|c|c|}
\hline Keterangan & 1984 & & 1987 & & 1990 & & 1993 \\
\hline \multicolumn{8}{|l|}{ Daerah Pedesaan } \\
\hline$(\mathrm{Rp})$ & 9.146 & & 12.247 & & 16.379 & & 21.228 \\
\hline$(\%)$ & 68,55 & & 67,21 & & 67,41 & & 63,59 \\
\hline \multicolumn{8}{|l|}{ - Bukan Makanan } \\
\hline (Rp) & 4.197 & & 5.926 & & 7.917 & & 12.517 \\
\hline$(\%)$ & 31,45 & & 32,79 & & 32,59 & & 36,41 \\
\hline \multicolumn{8}{|l|}{ Jumlah } \\
\hline Kenaikan (\%) & 13.343 & & 18.073 & 34,43 & 24.296 & & 33.385 \\
\hline Kenaikan rata-rata $(\%)$ & & 35,45 & & 35,76 & & 37,41 & \\
\hline \multicolumn{8}{|l|}{ Daerah Perkotaan } \\
\hline (Rp) & 13.632 & & 17.494 & & 22.633 & & 31.908 \\
\hline$(\%)$ & 54,10 & & 52,36 & & 51,40 & & 49,81 \\
\hline \multicolumn{8}{|l|}{ - Bukan Makanan } \\
\hline$(\mathrm{Rp})$ & 11.565 & & 15.919 & & 21.396 & & 32.155 \\
\hline$(\%)$ & 45,90 & & 47,64 & & 48,60 & & 50,19 \\
\hline Jumlah & 25.197 & & 33.413 & & 44.029 & & 64.063 \\
\hline Kenaikan (\%) & & & & 31,77 & & 45,50 & \\
\hline Kenaikan rata-rata (\%) & & 32.61 & & 36,63 & & & \\
\hline
\end{tabular}

Sumber: Dumairy. 1997, halaman 118, tabel 8.5 .

aksesnya terhadap bahan pangan sangat rendah.

Berdasar data Tabel 7, dari tahun 1990-1993 laju kenaikan pengeluaran rumah tangga perkotaan lebih tinggi dibanding rumah tangga pedesaan, ini berarti bahwa dengan berjalannya pembangunan, pedesaan menikmati hasil pembangunan yang lebih sedikit, atau dapat dinyatakan bahwa pedesaan menjadi daerah yang terpinggirkan secara ekonomi.

Apabila dihubungkan dengan sebagian besar rumah tangga pedesaan adalah petani, maka benar apabila dinyatakan bahwa sektor pertanian mengalami fase pengacuhan (ignorance) oleh para perumus kebijakan. Pada tahun 1990-an dimana kebijakan pembangunan ekonomi mengarah ke strategi industrialisasi, dimana berbagai komponen proteksi diberikan ke sektor industri, dan kemudian pertumbuhan sektor industri meningkat pesat, telah melumpuhkan basis pertanian di tingkat petani pedesaan. Proses tersebut pada akhirnya menimbulkan ketidakmerataan pembangunan antara pedesaan dan perkotaan (Arifin, 2004).

Selanjutnya data tahun 1996-2002, proporsi pengeluaran rumah tangga untuk bahan pangan antara rumah tangga pedesaan dan perkotaan kondisinya sama dengan periode sebelumnya, bahwa proporsi pengeluaran bahan pangan rumah tangga pedesaan (lebih dari 60 persen) lebih tinggi dibanding dengan rumah tangga perkotaan (sekitar 50 persen), lihat Tabel 8. 
Tabel 8. Pengeluaran Rata-rata Rumah Tangga 1996-2002 (persen)

\begin{tabular}{lccccc}
\hline Keterangan & \multirow{2}{*}{1996} & Pertambahan & 1999 & Pertambahan & \multirow{2}{*}{2002} \\
\hline Daerah Pedesaan & & & & & \\
- Makanan & 63,26 & 0,11 & 70,17 & $-0,06$ & 66,56 \\
- Bukan Makanan & 36,74 & $-0,19$ & 29,83 & 0,12 & 33,44 \\
Daerah Perkotaan & & & & & \\
- Makanan & 47,97 & 0,17 & 56,17 & $-0,06$ & 52,82 \\
- Bukan Makanan & 52,03 & $-0,16$ & 43,83 & 0,08 & 47,18 \\
\hline
\end{tabular}

Sumber: Survei Sosial Ekonomi Nasional, 1996, 1999, dan 2002, Syafa'at dkk. 2003, halaman 75 , tabel 10 , diolah

Dikaitkan dengan kondisi sekarang bahwa harga pangan cenderung meningkat, maka semakin sulit bagi masyarakat untuk dapat menjangkau ketersediaan pangan dalam jumlah yang cukup bagi keluarganya, terutama bagi rumah tangga dengan pendapatan tetap dan rumah tangga miskin.

Selanjutnya dikaitkan dengan petani sebagai produsen pangan, dimana pada kondisi sekarang, skala usahatani di pedesaan dicirikan oleh usaha kecil, sehingga sulit bagi petani untuk tetap survive apabila hanya mengandalkan pada usahataninya (on farm) sebagai sumber utama pendapatannya. Dengan demikian petani harus menganekaragamkan sumber pendapatannya dengan berbagai alternatif untuk menjamin pendapatannya, mungkin menanam komoditas pertanian bernilai ekonomi tinggi, dan atau bekerja di luar usahatani dan di luar pertanian (off farm dan non farm). Bagi masyarakat pedesaan, dengan semakin berkembangnya kegiatan non pertanian di pedesaan, maka diharapkan pendapatannya semakin tinggi dan semakin baik aksesnya terhadap bahan pangan. Untuk itu, pemerintah harus mengupayakan terwujudnya pedesaan sebagai kawasan pemukiman yang produktif, selalu mengembangkan diversifikasi ekonomi, dan mengembangkan infrastruktur pedesaan.

b. Harga Komoditas Pangan

Harga pangan menentukan daya beli masyarakat terhadap pangan, dan terdapat hubungan negatif antara keduanya. Harga yang meningkat (pada pendapatan tetap), maka daya beli menurun, dan sebaliknya apabila harga turun. Dengan demikian stabilitas harga pangan sangat penting untuk menjamin bahwa masyarakat dapat menjangkau kebutuhan pangannya. Perkembangan harga beberapa komoditas pangan tahun 2001-2005 di Jawa dan Bali menunjukkan peningkatan dari tahun ke tahun. Peningkatan terbesar adalah kedelai, dengan laju sebesar 86,67 persen dan gula pasir $(46,54 \%)$ selama kurun waktu tersebut, lihat Tabel 9. 
Tabel 9. Perkembangan Harga Beberapa Komoditas Pangan di Jawa-Bali, Tahun 2001-2005 (Rp/kg)

\begin{tabular}{lrrrrrc}
\hline \multicolumn{1}{c}{ Komoditas } & $\mathbf{2 0 0 1}$ & $\mathbf{2 0 0 2}$ & $\mathbf{2 0 0 3}$ & $\mathbf{2 0 0 4}$ & $\mathbf{2 0 0 5}$ & Perubahan (\%) \\
\hline Beras IR (medium) & 2.457 & 2.889 & 2.764 & 2.678 & 3.131 & 27,34 \\
Jagung & 1.925 & 2.123 & 2.175 & 2.243 & 2.353 & 22,23 \\
Kedelai & 2.604 & 3.120 & 3.148 & n.a & 4.861 & 86,67 \\
Gula Pasir & 3.769 & 3.588 & 4.344 & 4.233 & 5.523 & 46,54 \\
Minyak Goreng & 3.555 & 4.417 & 4.907 & 5.308 & 4.896 & 37,72 \\
Daging Sapi (murni) & 29.107 & 33.768 & 34.383 & 34.344 & 39.712 & 36,43 \\
Daging Ayam (ras) & 12.926 & 12.064 & 11.299 & 12.324 & 13.244 & 2,46 \\
Telur Ayam (ras) & 6.547 & 7.209 & 6.451 & 7.152 & 7.608 & 16,21 \\
\hline
\end{tabular}

Sumber: Badan BKP 2005, dalam Nainggolan, 2007, tabel 3, diolah.

Tabel 10. Perkembangan Harga Beberapa Komoditas Pangan di Tingkat Konsumen Tahun 2005-2007

\begin{tabular}{lllc}
\hline \multirow{2}{*}{ Komoditas } & \multicolumn{2}{c}{ Harga (Rp) } & \multirow{2}{*}{$\begin{array}{c}\text { Perubahan } \\
\text { (\%) }\end{array}$} \\
\cline { 2 - 3 } & $\mathbf{2 0 0 5}$ & $\mathbf{2 0 0 7}$ & \\
\hline Beras & 3.100 & 5.270 & 70,00 \\
Kedelai & 3.500 & 7.500 & 114,20 \\
Jagung & 1.100 & 2.300 & 109,09 \\
Tepung Terigu & 3.500 & 6.410 & 83,14 \\
Minyak Goreng & 5.000 & 9.150 & 83,00 \\
Gula Pasir & 5.000 & 6.750 & 35,00 \\
\hline
\end{tabular}

Sumber: BPS dan pedagang pasar, diolah

Pada awal tahun 2008, terjadi kenaikan yang tajam untuk beberapa harga pangan seperti kedelai dan jagung, selanjutnya diikuti dengan tepung terigu dan minyak goreng, lihat Tabel 10. Kenaikan harga ini sebagai dampak atas perubahan harga tersebut di pasar dunia, di mana di pasar dunia harga komoditas pangan yang mengalami kenaikan paling banyak adalah gandum (108,02 persen), dan minyak goreng (124,28 persen), sedangkan kedelai meningkat sebesar 59,46 persen pada tahun 2005-2007, lihat Tabel 11.
Kenaikan harga pangan di pasar dunia ini disebabkan menurunnya pasokan di pasar dunia. Penurunan pasokan ini terjadi dari gabungan tiga faktor yang saling memperkuat, yaitu kenaikan harga minyak bumi yang meningkatkan biaya produksi, perubahan iklim global dan konversi komoditas pangan ke bahan bakar nabati. Perubahan iklim menurunkan produksi gandum di Argentina dan Australia. Di Argentina berkurangnya produksi disebabkan musim dingin yang hebat, sedangkan di Australia dikarenakan kekeringan. 
Tabel 11. Perkembangan Harga Dunia Beberapa Komoditas Pangan Tahun 2005-2007

\begin{tabular}{llrrr}
\hline \multicolumn{1}{c}{ Komoditas } & \multicolumn{1}{c}{ Satuan } & 2005 & 2007 & Perubahan (\%) \\
\hline Beras putih,15\% & Dollar AS/ton & 274,67 & 324,80 & 18,25 \\
Gandum & Dollar AS/ton & 180,01 & 374,45 & 108,02 \\
Kedelai & Yen Jepang/60 kg & 338,45 & 539,68 & 59,46 \\
Gula & Sen dollar AS/lb & 9,85 & 10,07 & 2,23 \\
Jagung & Dollar AS/ton & 53,98 & 80,30 & 48,76 \\
Minyak sawit Sumatera & Dollar AS/ton & 420,23 & 942,50 & 124,28 \\
\hline
\end{tabular}

Sumber: Bank Indonesia, 2007

Kasus komoditi kedelai, berkurangnya produksi kedelai disebabkan karena terjadinya pengalihan lahan tanaman kedelai ke jagung. Jagung digunakan sebagai bahan bakar nabati (BBN) sebagai alternatif dari bahan bakar minyak (BBM). Kenaikan harga minyak bumi menjadikan negara AS dan China mulai tahun 2005 membuat kebijakan strategis, yaitu pengembangan bahan bakar nabati berbasis komoditas bijibijian seperti jagung. AS sebagai produsen kedelai terbesar di pasar dunia meningkatkan produksi jagung untuk memenuhi kebutuhan pengalihan konsumsi BBM ke BBN dalam bentuk etanol yang berbasis jagung. Upaya peningkatan produksi jagung dilakukan dengan memberikan insentif yang mendorong petani untuk menanam jagung daripada kedelai, akibatnya produksi kedelai turun (sekitar 16 juta ton di AS sedang 14 juta ton di dunia). Demikian halnya China, meningkatkan produksi jagung untuk keperluan $\mathrm{BBN}$, sehingga produksi kedelei turun (1,7 juta ton).

Gejala naiknya harga pangan di pasar dunia, nampaknya masih akan berlanjut. Pengembangan bahan bakar alternatif berbasis biji-bijian sebagai respon dari naiknya harga minyak mentah dunia, akan membawa dampak pada berkurangnya pasokan pangan di pasar dunia. Sementara Indonesia dengan jumlah penduduk lebih dari 210 juta dan pertumbuhannya positif, apabila tidak melakukan antisipasi terhadap pernurunan pasokan dan lonjakan harga pangan dunia, akan berdampak pada rentannya akses masyarakat atau rumah tangga terhadap pangan. (Swastika, 2006)

\section{Konsumsi Pangan}

Konsumsi pangan bekaitan dengan gizi yang cukup dan seimbang. Tingkat dan pola konsumsi pangan dan gizi dipengaruhi oleh kondisi ekonomi, sosial dan budaya setempat. Konsumsi pangan rumah tangga diukur dari konsumsi energi dan konsumsi protein, dimana konsumsi energi penduduk Indonesia pada tahun 2005 sebesar 1.997 kkal/kap/hari, masih lebih rendah dari yang direkomendasikan WKNPG (Widya Karya Nasional Pangan dan Gizi) VIII tahun 2004 sebesar $2.000 \mathrm{kkal} / \mathrm{kap} / \mathrm{hari}$. Data Susenas tahun 1999-2005 mengenai konsumsi energi disajikan dalam Tabel 12. 
Tabel 12. Konsumsi Energi Penduduk Indonesia Tahun1999-2005 (kkal/kap/hari)

\begin{tabular}{llrrrrr}
\hline No & \multicolumn{1}{c}{ Kelompok Pangan } & $\mathbf{1 9 9 9}$ & $\mathbf{2 0 0 2}$ & $\mathbf{2 0 0 3}$ & $\mathbf{2 0 0 4}$ & $\mathbf{2} 2005$ \\
\hline 1. & Padi-padian & 1240,2 & 1230,0 & 1251,6 & 1248,2 & 1236,24 \\
& * Beras & 1084,0 & 1070,0 & 1067,7 & 1056,4 & 1033,5 \\
& * Jagung & 27,9 & 28,0 & 22,5 & 23,8 & 22,42 \\
& * Terigu & 128,3 & 155,0 & 161,3 & 168,1 & 180,32 \\
2. & Umbi-umbian & 69,0 & 70,0 & 66,4 & 77,3 & 72,71 \\
3. & Pangan hewani & 88,3 & 117,0 & 138,4 & 134,1 & 136,27 \\
4. & Minyak dan lemak & 170,5 & 205,0 & 194,9 & 194,6 & 198,91 \\
5. & Buah/biji berminyak & 40,6 & 52,0 & 55,8 & 47,3 & 49,28 \\
6. & Kacang-kacangan & 53,8 & 62,0 & 61,7 & 64,3 & 67,32 \\
7. & Gula & 92,4 & 96,0 & 100,6 & 100,7 & 99,06 \\
8 & Sayuran dan buah & 70,48 & 78 & 89,8 & 86,97 & 91,41 \\
9. & Lain-lain (minuman dan bumbu-bumbuan) & 25,6 & 53 & 31,5 & 32,63 & 45,20 \\
& $\quad$ TOTAL & 1851 & 1986 & 1991 & 1986 & 1997 \\
& PPH & 66,3 & 72,6 & 77,5 & 76,9 & 78,2 \\
\hline
\end{tabular}

Sumber: Susenas 1999, 2002, 2003 dan 2004 dan Pusat Konsumsi Pangan BKP 2006, dalam Nainggolan, 2006, tabel 4, diolah.

Tabel 13. Rata-rata Konsumsi Protein Penduduk Indonesia Tahun1999-2005 (gram/kap/hari)

\begin{tabular}{ccccccc}
\hline No & Uraian & $\mathbf{1 9 9 9}$ & $\mathbf{2 0 0 2}$ & $\mathbf{2 0 0 3}$ & $\mathbf{2 0 0 4}$ & $\mathbf{2 0 0 5}$ \\
\hline 1. & Perkotaan & 49,32 & 55,98 & 56,71 & 55,91 & 55,26 \\
& Persentase & $(94,85)$ & $(107,65)$ & $(109,06)$ & $(107,52)$ & $(106,27)$ \\
2. & Pedesaan & 48,24 & 53,19 & 54,38 & 53,68 & 55,28 \\
& Persentase & $(92,27)$ & $(102,29)$ & $(104,58)$ & $(103,23)$ & $(106,31)$ \\
3. & Nasional & 48,67 & 54,42 & 55,37 & 54,65 & 56,27 \\
& Persentase & $(93,57)$ & $(104,65)$ & $(106,48)$ & $(105,10)$ & $(106,29)$ \\
\hline
\end{tabular}

Sumber: Susenas 1999, 2002, 2003 dan 2004 dan Pusat Konsumsi Pangan BKP 2006 dalam Nainggolan, 2006, tabel 5. Keterangan: angka dalam kurung merupakan persentase dari angka kecukupan protein $52 \mathrm{gram} / \mathrm{kap} / \mathrm{hari}$

Data mengenai konsumsi beras per kapita menunjukkan bahwa rata-rata konsumsi beras sekitar $141 \mathrm{~kg} / \mathrm{kap} / \mathrm{tahun}$, yang terdiri dari konsumsi rumah tangga 120 $\mathrm{kg} / \mathrm{kap} /$ tahun dan industri pengolahan sebesar $120 \mathrm{~kg} / \mathrm{kap} /$ tahun (Nainggolan, 2006). Bandingkan dengan Jepang $60 \mathrm{~kg} / \mathrm{kapita} / \mathrm{tahun}$ (Soetrisno, 2005). Selanjutnya konsumsi protein penduduk mulai tahun 2002 sudah melebihi konsumsi protein yang direkomendasikan sebesar 52 gram/kap/hari. Pada tahun
2005 untuk angka nasional sebesar 56,27 gram/kap/hari, lihat Tabel 13.

Indikator kualitas konsumsi pangan ditunjukkan oleh skor PPH (Pola Pangan Harapan) yang dipengaruhi oleh keragaman dan keseimbangan konsumsi antar kelompok pangan, menunjukkan bahwa telah terjadi peningkatan mutu gizi konsumsi pangan penduduk Indonesia yang diindikasikan meningkatnya skor PPH dari tahun 1999 $(66,3)$ ke tahun $2005(78,2)$, lihat Tabel 12. 


\section{Permasalahan dalam Ketahanan Pangan}

Permasalahan secara umum mengenai ketahanan pangan adalah jumlah penduduk yang besar dengan pertumbuhan penduduk yang positif. Dengan demikian permintaan pangan masih akan meningkat. Peningkatan permintaan pangan juga didorong oleh peningkatan pendapatan, kesadaran akan kesehatan dan pergeseran pola makan karena pengaruh globalisasi, serta ragam aktivitas masyarakat. Di sisi lain, ketersediaan sumber daya lahan semakin berkurang, karena tekanan penduduk serta persaingan pemanfaatan lahan antara sektor pangan dengan sektor non pangan. Secara spesifik, permasalahan sehubungan dengan ketahanan pangan adalah penyediaan, distribusi, dan konsumsi pangan.

\section{Penyediaan Pangan}

Penyediaan pangan melalui peningkatan produksi pangan dalam negeri dihadapkan pada masalah pokok yaitu semakin terbatas dan menurunnya kapasitas produksi. Desakan peningkatan penduduk beserta aktivitas ekonominya menyebabkan: (1) terjadinya konversi lahan pertanian ke non pertanian, (2) menurunnya kualitas dan kesuburan lahan akibat kerusakan lingkungan, (3) semakin terbatas dan tidak pastinya penyediaan air untuk produksi akibat kerusakan hutan, (4) rusaknya sekitar 30 persen prasarana pengairan, dan (5) persaingan pemanfaatan sumber daya air dengan sektor industri dan pemukiman (Nainggolan, 2006).

Secara rinci faktor penyebab terbatas dan menurunnya kapasitas produksi dapat dikelompokkan dalam faktor teknis dan sosial ekonomi sebagai berikut: a. Faktor teknis:

- Berkurangnya lahan pertanian karena alih lahan pertanian ke non pertanian, yang diperkirakan laju peningkatannya $1 \% /$ tahun.

- Produktifitas pertanian yang relatif rendah dan tidak meningkat.

- Teknologi produksi yang belum efektif dan efisien.

- Infrastruktur pertanian (irigasi) yang tidak bertambah dan kemampuannya semakin menurun.

- Tingginya proporsi kehilangan hasil pada penanganan pasca panen (10$15 \%)$.

- Kegagalan produksi karena faktor iklim yang berdampak pada musim kering dan banjir.

b. Faktor sosial-ekonomi:

- Penyediaan sarana produksi yang belum sepenuhnya terjamin oleh pemerintah.

- Sulitnya mencapai tingkat efisiensi yang tinggi dalam produksi pangan karena besarnya jumlah petani (21 juta rumah tangga tani) dengan lahan produksi yang semakin sempit dan terfragmentasi (laju 0,5 persen/ tahun).

- Tidak adanya jaminan dan pengaturan harga produk pangan yang wajar dari pemerintah kecuali beras.

- Tataniaga produk pangan yang belum pro petani termasuk kebijakan tarif impor yang melindungi kepentingan petani.

- Terbatasnya devisa untuk impor pangan. 


\section{Distribusi Pangan}

Distribusi pangan adalah kegiatan menyalurkan bahan pangan dari point of production (petani produsen) kepada point of consumption (konsumen akhir). Distribusi tidak hanya menyangkut distribusi pangan di dalam negeri namun juga menyangkut perdagangan internasional dalam suatu sistem harga yang terintegrasi secara tepat (Soetrisno, 2005). Dengan demikian perlu dibuat pola distribusi pangan yang menjamin seluruh rumah tangga dapat memperoleh pangan dalam jumlah yang cukup sepanjang waktu dengan harga yang terjangkau. Permasalahan dalam distribusi pangan (Nainggolan, 2006):

- Prasarana distribusi darat dan antar pulau yang diperlukan untuk menjangkau seluruh wilayah konsumen belum memadai, sehingga wilayah terpencil masih mengalami keterbatasan pasokan pangan pada waktu-waktu tertentu. Keadaan ini menghambat aksesibilitas masyarakat terhadap pangan, baik secara fisik, namun juga secara ekonomi, karena kelangkaan pasokan akan memicu kenaikan harga dan mengurangi daya beli masyarakat.

- Kelembagaan pemasaran belum mampu berperan, baik sebagai penyangga kestabilan distribusi maupun harga pangan. Pada masa panen, pasokan pangan berlimpah ke pasar sehingga menekan harga produk pertanian dan mengurangi keuntungan usahatani. Sebaliknya pada masa paceklik atau masa dimana panen tidak berhasil, harga meningkat dengan tajam, sehingga mengurangi aksesibilitas masyarakat terhadap pangan.

- Bervariasinya kemampuan produksi antar wilayah dan antar musim menuntut kecermatan dalam mengelola sistem distribusi pangan, agar pangan tersedia sepanjang waktu di seluruh wilayah konsumen.

- Keamanan jalur distribusi dan adanya pungutan sepanjang jalur distribusi dan pemasaran, mengakibatkan biaya distribusi yang tinggi pada berbagai produk pangan.

\section{Konsumsi Pangan}

Permasalahan mengenai konsumsi penduduk Indonesia adalah belum terpenuhinya kebutuhan pangan, karena belum tercukupinya konsumsi energi (meskipun konsumsi protein sudah mencukupi). Konsumsi energi penduduk Indonesia masih lebih rendah dari yang direkomendasikan WKNPG VIII. Permasalahan selanjutnya adalah mengenai konsumsi energi yang sebagian besar dari padi-padian, dan bias ke beras, lihat tabel 12. Dengan demikian diperlukan upaya untuk mendiversifikasikan konsumsi pangan dengan sumber karbohidrat non beras dan pangan sumber protein, menganekaragamkan kualitas konsumsi pangan dengan menurunkan konsumsi beras per kapita, selain mengembangkan industri dan bisnis pangan yang lebih beragam.

\section{Strategi dan Kebijakan Ketahanan Pangan}

Kebijakan pangan pemerintah sebagai pelaksanaan Undang-undang Nomor 7 tahun 1996, dituangkan dalam Peraturan Pemerintah nomor 68 tahun 2002 mengenai ketahanan pangan, yang secara garis besar mengatur:

- Ketersediaan pangan

Dilakukan dengan pengembangan sistem produksi, efisiensi sistem usaha pangan, teknologi produksi pangan, sarana dan 
prasarana produksi pangan dan mempertahankan lahan produktif.

- Cadangan pangan nasional

Berasal dari cadangan pangan masyarakat dan cadangan pemerintah (dari tingkat desa, kabupaten/kota, propinsi sampai pemerintah pusat). Selanjutnya cadangan masyarakat dilakukan oleh lembaga swadaya masyarakat, organisasi masyarakat, swasta, koperasi dan atau perorangan.

- Penganekaragaman pangan

Konsumsi pangan yang beraneka ragam dengan prinsip gizi yang seimbang.

- Pencegahan dan penanggulangan masalah pangan

Suatu langkah antisipatif untuk menghindari terjadinya masalah pangan (kelebihan/kekurangan pangan dan kemampuan rumah tangga dalam memenuhi kebutuhan pangan).

- Peran pemerintah daerah dan masyarakat Pemerintah daerah melaksanakan jakan ketahanan pangan di wilayahnya masingmasing melalui pemberian informasi dan pendidikan, meningkatkan motivasi masyarakat dan kemandirian rumah tangga dalam meningkatkan ketahanan pangan. Selanjutnya peran masyarakat dalam ketahanan pangan dilakukan melalui kegiatan produksi, perdagangan dan distribusi pangan, serta cadangan pangan.

- Pengembangan sumber daya manusia dan kerjasama internasional

Pengembangan sumber daya manusia dilakukan melalui pendidikan/ pelatihan di bidang pangan, penyebarluasan ilmu dan teknologi di bidang pangan, serta penyuluhan pangan. Kerjasama interna- sional meliputi bidang produksi, perdagangan dan distribusi pangan; cadangan pangan; pencegahan dan penanggulangan masalah pangan; serta riset dan teknologi pangan.

Badan Ketahanan Pangan menyusun kebijakan umum mengenai ketahanan pangan yang arahnya adalah mewujudkan kemandirian pangan untuk menjamin ketersediaan dan konsumsi pangan yang cukup, aman, bermutu, dan bergizi seimbang pada tingkat rumah tangga, daerah dan nasional sepanjang waktu dan merata melalui pemanfaatan sumber daya dan budaya lokal, teknologi inovatif dan peluang pasar, serta memperkuat ekonomi kerakyatan dan mengentaskan dari kemiskinan.

\section{Kebijakan Umum}

Substansi kebijakan umum ketahanan pangan terdiri dari 14 elemen penting, yang tersusun dalam rencana aksi pangan periode 20062009, yang diharapkan menjadi panduan pelaksanaan kebijakan umum di tingkat lapangan, yaitu para pelaksana dan para stakeholders ketahanan pangan yang meliputi lembaga pemerintah, swasta, BUMN, perguruan tinggi, lembaga swadaya masyarakat dan kalangan masyarakat umum. Rencana aksi tersebut tertuang dalam kegiatan operasional yang disusun dalam bentuk matriks, memuat tujuan kebijakan, dimana masingmasing tujuan tersebut memuat kegiatan, instansi sebagai penanggungjawab, dan indikator keberhasilan. Secara garis besar disajikan dalam tulisan ini adalah tujuan kebijakan dan kegiatan pada setiap tujuan, sebagai berikut (Badan Ketahanan Pangan):

a. Tujuan Kebijakan: Menjamin ketersediaan pangan 
Kegiatan:

- Pengembangan lahan abadi 15 juta ha lahan sawah beririgasi dan 15 juta ha lahan kering.

- Pengembangan konservasi dan rehabilitasi lahan.

- Pelestarian sumber daya air dan pengelolaan daerah aliran sungai.

- Pengembangan dan penyediaan benih, bibit unggul, dan alsintan.

- Pengaturan pasokan gas untuk memproduksi pupuk.

- Pengembangan skim permodalan bagi petani/nelayan.

- Peningkatan produksi dan produktivitas (perbaikan genetik dan teknologi budidaya).

- Pencapaian swasembada lima komoditas strategis (padi, jagung, kedelai, tebu, daging sapi).

- Penyediaan insentif investasi di bidang pangan termasuk industri gula, peternakan dan perikanan.

- Penguatan penyuluhan petani/nelayan dan kemitraan.

b. Tujuan Kebijakan: Menata pertanahan dan tata ruang serta wilayah

Kegiatan:

- Pengembangan reforma agraria.

- Penyusunan tata ruang daerah dan wilayah.

- Perbaikan administrasi pertanahan dan sertifikasi lahan.

- Pengenaan sistem perpajakan progresif bagi pelaku konversi lahan pertanian subur dan yang mentelantarkan lahan pertanian.

c. Tujuan Kebijakan: Mengembangkan cadangan pangan
Kegiatan:

- Pengembangan cadangan pangan pemerintah (nasional, daerah dan desa).

- Pengembangan lumbung pangan masyarakat.

d. Tujuan Kebijakan: Mengembangkan sistem distribusi pangan yang adil dan efisien

Kegiatan:

- Pembangunan dan rehabilitasi sarana dan prasarana distribusi.

- Penghapusan retribusi produk pertanian dan perikanan.

- Pemberian subsidi transpotasi bagi daerah yang sangat rawan pangan dan daerah terpencil.

- Pengawasan sistem persaingan perdagangan yang tidak sehat.

e. Tujuan Kebijakan: Menjaga stabilitas harga pangan

Kegiatan:

- Pemantauan harga pangan pokok secara berkala untuk mencegah jatuhnya harga gabah/beras dibawah HPP.

- Pengelolaan pasokan pangan dan cadangan penyangga untuk stabilitas harga pangan.

f. Tujuan Kebijakan: Meningkatkan aksesibilitas rumah tangga terhadap pangan

Kegiatan:

- Pemberdayaan masyarakat miskin dan rawan pangan

- Peningkatan efektivitas program raskin. 
g. Tujuan Kebijakan: Melakukan diversifikasi pangan

Kegiatan:

- Peningkatan diversifikasi konsumsi pangan dengan gizi seimbang.

- Pemberian makanan tambahan untuk anak sekolah (PMTAS).

- Pengembangan teknologi pangan.

- Diversifikasi usahatani dan pengembangan pangan lokal.

h. Tujuan Kebijakan: Meningkatkan mutu dan keamanan pangan

Kegiatan:

- Pengembangan dan penerapan sistem mutu pada proses produksi olahan dan perdagangan pangan.

- Peningkatan kesadaran mutu dan keamanan pangan bagi konsumen.

- Pencegahan dini dan penegakan hukum terhadap pelanggaran aturan mutu dan keamanan pangan.

i. Tujuan Kebijakan: Mencegah dan menangani keadaan rawan pangan

Kegiatan:

- Pengembangan isyarat dini dan penanggulangan keadaan rawan pangan.

- Peningkatan keluarga sadar gizi melalui penyuluhan dan bimbingan sosial dengan menyempurnakan sistem komunikasi,informasi dan edukasi (KIE).

- Pemanfaatan lahan pekarangan untuk peningkatan gizi keluarga.

j. Tujuan Kebijakan: Memfasilitasi penelitian dan pengembangan

Kegiatan:
- Alokasi anggaran negara yang memadai untuk penelitian dan pengembangan.

- Peningkatan kerjasama dan kemitraan antara lembaga penelitian.

k. Tujuan Kebijakan: Meningkatkan peran serta masyarakat

Kegiatan:

- Pemberian penghargaan bagi masyarakat yang berjasa pada pembangunan ketahanan pangan dan gizi.

1. Tujuan Kebijakan: Melaksanakan kerjasama internasional

Kegiatan:

- Penanggulangan kerjasama internasional dalam melawan kelaparan dan kemiskinan.

- Perbaikan kinerja diplomasi ekonomi, sosial dan budaya untuk meningkatkan ketahanan pangan.

m. Tujuan Kebijakan: Mengembangkan sumber daya manusia

Kegiatan:

- Perbaikan program pendidikan, pelatihan dan penyuluhan pangan.

- Pemberian muatan pangan dan gizi pada pendidikan formal dan non formal.

- Pemberian jaminan pendidikan dasar dan menengah, khususnya bagi perempuan dan anak-anak di pedesaan.

n. Tujuan Kebijakan: Kebijakan makro dan perdagangan yang kondusif

Kegiatan: 
- Kebijakan fiskal yang memberikan insentif dan keringanan pajak bagi usaha pertanian dan bisnis pangan.

- Alokasi APBN dan APBD yang memadai bagi pengembangan sektor pertanian dan pangan.

- Kebijakan perdagangan yang memberikan proteksi dan promosi bagi produk pertanian strategis.

\section{Arah dan Strategi Kebijakan}

Arah dari pembangunan ketahanan pangan adalah mencapai sasaran tingkat mikro (tingkat rumah tangga/individu) dan tingkat makro (nasional). Sasaran diindikatorkan sebagai berikut (Badan Ketahanan Pangan):

a. Tingkat Mikro (rumah tangga)

- Dipertahankannya ketersediaan energi perkapita minimal 2.200 kilokalori/hari, dan penyediaan protein perkapita minimal 57 gram/hari.

- Meningkatnya kemampuan pemanfaatan dan konsumsi pangan perkapita untuk memenuhi kecukupan energi minimal 2.000 kilokalori/hari dan protein perkapita minimal 57 gram/hari, dengan skor PPH minimal sebesar 80 .

- Berkurangnya jumlah penduduk yang rawan pangan kronis (yang mengkonsumsi kurang dari 80 persen $\mathrm{AKG}$ ) menjadi 1 persen, termasuk di dalamnya ibu hamil yang mengalami anemia gizi dan balita dengan gizi kurang.

- Tertanganinya secara cepat penduduk yang mengalami rawan pangan transien di daerah karena bencana alam dan bencana nasional
- Meningkatnya rata-rata penguasaan lahan petani.

b. Tingkat Makro (nasional)

- Meningkatnya kemandirian pangan yang diwujudkan melalui pencapaian swasembada beras berkelanjutan. Swasembada jagung pada tahun 2007, swasembada kedelai pada tahun 2015, swasembada gula pada tahun 2009 dan swasembada daging sapi pada tahun 2010; serta membatasi impor pangan utama di bawah 10 persen dari kebutuhan pangan nasional.

- Meningkatnya land-man rasio melalui penetapan lahan abadi beririgasi minimal 15 juta ha, dan lahan kering minimal 15 juta ha.

- Meningkatnya kemampuan pengelolaan cadangan pangan pemerintah daerah dan pemerintah pusat.

- Meningkatnya jangkauan jaringan distribusi dan pemasaran pangan yang berkeadilan ke seluruh daerah bagi produsen dan konsumen.

- Meningkatnya kemampuan pemerintah dalam mengenali, mengantisipasi, dan menangani secara dini, serta dalam melakukan tanggap darurat terhadap masalah kerawanan pangan dan gizi.

Strategi pelaksanaan kebijakan umum menuju kepada sasaran dilakukan melalui jalur ganda (twin-track strategy) (Badan Ketahanan Pangan):

- Membangun ekonomi berbasis pertanian dan pedesaan untuk menyediakan lapangan kerja dan pendapatan.

- Memenuhi pangan bagi kelompok masyarakat miskin dan rawan pangan 
melalui pemberian bantan langsung agar tidak semakin terpuruk, serta pemberdayaan agar mereka semakin mampu mewujudkan ketahanan pangannya secara mandiri.

Kedua strategi ini dijalankan dengan melibatkan seluruh komponen bangsa yaitu pemerintah, masyarakat termasuk LSM, organisasi profesi, organisasi massa, organisasi sosial, koperasi dan pelaku usaha.

Pemerintah menandaskan bahwa kebijakan ketahanan pangan difokuskan kepada pemberdayaan rumah tangga dan masyarakat agar mampu menolong dirinya sendiri dalam mewujudkan ketahanan pangan dan mengatasi masalah-masalah pangan yang dihadapi. Pemberdayaan masyarakat tersebut diupayakan melalui peningkatan kapital dan kapasitas rumah tangga agar mampu memproduksi, mengolah dan memasarkan produk pangan, serta mampu memasuki pasar tenaga kerja dan memberikan kesempatan berusaha guna meningkatkan pendapatan rumah tangga.

\section{Pemberdayaan Ketahanan Pangan Masyarakat}

Kecukupan pangan nasional tidak menjamin bahwa semua rumah tangga memperoleh pangan yang dibutuhkannya, sehingga fokus ketahanan pangan adalah rumah tangga. Dengan demikian kebijakan ketahanan pangan difokuskan kepada pemberdayaan rumah tangga dan masyarakat agar mampu menolong dirinya sendiri dalam mewujudkan ketahanan pangan dan mengatasi masalahmasalah pangan yang dihadapi.

Seiring dengan otonomi daerah, maka proses pemberdayaan didesentralisasikan sesuai dengan potensi dan keragaman sumber daya wilayah. Demikian juga mengenai kesempatan berusaha, bahwa usaha yang dilakukan tidak harus pada usahatani padi, tapi juga usahatani non padi (on-fram), offfarm bahkan non-farm. Pada intinya upaya peningkatan ketahanan pangan tidak fokus pada pengembangan pertanian dalam arti primer, namun juga sistem dan usaha agribisnis (Tauchid, 2007). Tujuan utama pembangunan ketahanan pangan tingkat rumah tangga adalah meningkatnya daya beli rumah tangga melalui peningkatan pendapatannya.

Ketahanan pangan rumah tangga tidaklah berdiri sendiri, namun secara hierarkis berkaitan dengan ketahanan pangan tingkat regional (kabupaten-propinsi) dan ketahanan pangan tingkat nasional (Simatupang, 2007). Pada tingkat rumah tangga, penanggunggjawab adalah kepala keluarga, dengan stakeholder-nya seluruh anggota keluarga. Pada tingkat regional, penanggungjawab adalah pemerintah daerah dengan stakeholder-nya desa-desa di dalam wilayah yuridiksinya. Pada tingkat nasional penanggunggjawab adalah pemerintah pusat atau negara. Secara hierarkis ketahanan pangan keluarga ditentukan oleh ketahanan pangan regional dan nasional. Pemerintah pusat memfasilitasi pemerintah daerah dalam upayanya mewujudkan ketahanan pangan di wilayahnya.

Dalam rangka membangun ketahanan pangan rumah tangga tersebut, maka fokus pembangunan ketahanan pangan adalah pemberdayaan masyarakat, yang berarti meningkatkan kemandirian dan kapasitas masyarakat untuk berperan aktif dalam mewujudkan ketersediaan, distribusi dan konsumsi pangan dari waktu ke waktu. Pemberdayaan ketahanan pangan masyarakat diimplementasikan melalui program Desa Mandiri Pangan yang dimulai pada tahun 
2005 (Nainggolan, 2006). Pemantapan ketahanan pangan masyarakat melalui program ini adalah mewujudkan ketahanan pangan rumah tangga yang secara kumulatif diharapkan dapat menopang ketahanan pangan di tingkat desa dan tingkat wilayah.

Prinsip pengembangan model desa mandiri pangan adalah: (i) kemampuan pengelolaan ketahanan pangan di tingkat desa, (ii) kemampuan upaya pemanfaatan sumber daya yang dimiliki untuk meningkatkan kualitas pemenuhan kebutuhan pangan, (iii) kemampuan menangani masalah kelebihan/kekurangan pangan dan ketidakmampuan masyarakat dalam mengakses pangan, serta (iv) prinsip-prinsip pemberdayaan ketahanan pangan secara partisipatif dan berkelanjutan (Nainggolan, 2004).

Strategi dalam pengembangan desa mandiri pangan adalah (Nainggolan, 2004):

- Mewadahi partisipasi masyarakat desa dalam keseluruhan sistem ketahanan pangan melalui berbagai bentuk pengembangan usaha, kerjasama dan kemitraan.

- Memaksimalkan potensi dan pemanfaatan sumber daya pangan di pedesaan melalui rehabilitasi kemampuan dan optimalisasi pemanfaatan sumber daya pangan.

- Mendekatkan fasilitasi aparat kepada masyarakat di pedesaan dalam upaya pemantapan ketahanan pangan.

- Memfasilitasi pemecahan masalah dan kendala masyarakat dalam mewujudkan ketahanan pangan di pedesaan.

- Memberikan penghargaan serta mengakomodasikan peran kelompok masyarakat dalam mewujudkan ketahanan pangan di pedesaan.
Indikator keberhasilan program aksi desa mandiri pangan adalah (Nainggolan, 2004):

- Terbentuknya kelompok pangan desa dan kader pangan masyarakat yang tumbuh dari kesadaran sendiri serta merepresentasikan seluruh komponen masyarakat pedesaan.

- Tumbuh dan berkembangnya kembali rembug desa melalui pertemuan kelompok pangan secara reguler dan diikuti oleh semua kader pangan desa.

- Kader pangan desa mampu mendampingi masyarakat di desanya dalam mewujudkan ketahanan pangan.

- Jumlah rumah tangga rawan pangan menurun secara nyata.

Pada tahun 2006, program desa mandiri pangan dilaksanakan di 122 kabupaten (Nainggolan, 2006), sementara pada tahun 2007 meliputi 200 desa di seluruh propinsi dan kabupaten di Indonesia (Apriyantono, 2007).

Sebagai ilustrasi, beberapa wilayah yang berhasil diakses mengenai program desa mandiri pangan adalah:

- Propinsi Jawa Tengah

Pada tahun 2005 mempersiapkan program aksi desa mandiri pangan. Persiapan dilakukan dengan mengkaji model pengembangan desa mandiri pangan bekerjasama dengan Pusat Studi Pedesaan Universitas Gadjah Mada Jogjakarta. Daerah kajian adalah Demak, Grobogan, Karanganyar dan Sukoharjo. Kriteria lokasi program adalah kabupaten, kecamatan dan desa rawan pangan dengan tingkat kemiskinan dan risiko tinggi. Fokus pelaksanaan program adalah penguatan kelembagaan penyulu- 
han, produksi pangan dan pelayanan usaha produksi dan agribisnis pangan.

Pada tahun 2007 di Grobogan mencanangkan pembangunan desa mandiri pangan di 42 desa yang ada di 16 kecamatan. Pelaksanaan program dengan mendirikan lumbung desa sebagai tempat yang menampung gabah hasil panen dan didistribusikan manakala musim paceklik tiba (http://tempointeraktif.com/hg/nusa/ jawamadura/2007/05/29/brk.).

- Propinsi Jawa Timur

Pelaksanaan program desa mandiri pangan di kabupaten yang memiliki kriteria: memiliki unit kerja yang menangani ketahanan pangan, telah terbentuk dewan ketahanan pangan kabupaten, bersedia menyediakan dana pendamping dari APBD (minimal 20 persen dari dana APBN), merupakan kabupaten rawan pangan berdasarkan kriteria FIA.

Pada tahun 2006 lokasi program desa mandiri pangan adalah Kabupaten Pacitan, Bojonegoro, Bondowoso dan Pamekasan.

Pada tahun 2007 dikembangkan di 11 kabupaten (Badan Ketahanan Pangan Propinsi Jawa Timur).

\section{- Propinsi Sumatera Utara}

Pelaksanaan program desa mandiri pangan tahun 2007 akan dilaksanakan di 9 kabupaten dan kota, yaitu Nias, Labuhan Batu, Dairi, Meda, Binjai, Padangsidempuan, Tapanuli Selatan, Tapanuli Tengah dan Manadailing Natal (http://groups.google.co.id/group/milisfpk/browse_thread/thread/53c5).
- Kabupaten Sinjai, program dilaksanakan di wilayah yang mempunyai banyak rumah tangga miskin. Pada tahun 2006 dilaksanakan di kecamatan Bulupoddo di desa Tompobulu dan desa Duanpanuae. Tahun 2007 di kecamatan Telluluimpoe pada dua desa dengan rumah tangga miskin terbanyak (Situs Resmi Pemerintah Kabupaten Sinjai).

\section{Lumbung Pangan sebagai Cadangan Pangan Masyarakat}

Keberadaan lumbung pangan atau lumbung desa pernah berperan sangat penting dalam menyangga ketersediaan pangan di desa. Fungsi strategis lumbung desa pada jaman dulu adalah:

- Sebagai cadangan penyediaan pangan

- Pada keadaan dimana gagal panen karena adanya hama atau bencana alam, maka keperluan pangan dipenuhi dengan cadangan pangan yang ada di lumbung.

- Sebagai sarana untuk meningkatkan posisi tawar petani

- Pada saat terjadi kelebihan produksi ketika saat panen raya, petani dapat mengatur supply-nya dengan menyimpan hasil panennya di lumbung, dan akan dilempar ke pasar pada waktu harga lebih baik.

- Sebagai tempat penyimpan benih

Pada waktu panen, hasilnya dipilah dan yang kualitasnya baik disimpan di lumbung sebagai benih.

- Mempunyai peran sosial

Lumbung desa mempunyai peran sosial di antaranya membantu kebutuhan pangan petani dalam masa paceklik. 
Lumbung pangan juga didapati di setiap rumah tangga petani. Rumah tangga petani mempunyai ruang khusus atau tempat khusus sebagai tempat penyimpan hasil panen dan benih.

Keberadaan lumbung desa yang mempunyai fungsi sosial dan dikelola secara bersama, akan menumbuhkan rasa sosial di antara anggotanya, dan ini merupakan modal sosial bagi pembangunan. Dengan demikian perlu menumbuhkan lumbung desa atau meningkatkan fungsi lumbung desa yang telah ada, apalagi bila dilakukan pada desa mandiri pangan yang telah dirintis oleh pemerintah. Keberadaan lumbung pangan diarahkan menuju lumbung desa sebagai sarana untuk pemupukan cadangan pangan masyarakat yang fungsinya adalah mewujudkan ketersediaan, distribusi dan konsumsi pangan dari waktu ke waktu.

Kajian terhadap keberadaan lumbung pangan masyarakat oleh Pusat Pengembangan Ketersediaan Pangan dilakukan pada tahun 2002, di propinsi Jawa Barat dan Jawa Tengah. Di Propinsi Jawa Barat, kajian dilakukan di Kabupaten Tasikmalaya, Cirebon dan Cianjur, sedangkan Propinsi Jawa Tengah, di Kabupaten Banyumas, Purworejo, dan Boyolali. Hasil kajiannya sebagai berikut:

- Modal awal lumbung pangan berbentuk natura yaitu gabah yang disetor sekali pada waktu pembentukan. Selanjutnya tidak ada aktivitas penyimpanan (setor). Aktivitas yang ada adalah peminjaman dan pengembalian dalam bentuk natura. Penggunaan pinjaman untuk konsumsi pada masa paceklik dan bantuan musibah (di Tasikmalaya), selain itu juga untuk modal kerja usahatani (di Cirebon dan Cainjur).
- Di Jawa Tengah, lumbung desa dianggap sebagai kelembagaan desa yang mendukung ketahanan pangan, dimiliki oleh semua desa (8.530 desa). Dari sejumlah tersebut, 25,12 persen (2.143 desa) mempunyai lumbung desa secara fisik sebagai tempat menyimpan bahan pangan (padi/ gabah, jagung dan sembako).

- Kapasitas rata-rata lumbung untuk menyerap marketable surplus relatif kecil dan bervariasi. Kapasitas simpan rata-rata di Jawa Barat adalah 0,59 persen (dengan marketable surplus sekitar 4 juta ton), sedang di Jawa Tengah sebesar 0,92 persen (dengan marketable surplus sekitar 4,5 juta ton GKG).

- Jasa peminjaman bervariasi antara 0-30 persen dalam bentuk natura per musim. Penggunaan jasa pinjaman untuk akumulasi modal, susut, jasa pengurus dan anggota, serta untuk kegiatan sosial seperti bantuan musibah, pengembangan infrastruktur pedesaan. Ada lumbung desa yang tidak memberikan jasa kepada pengurus.

- Berdasar hasil kajian tersebut maka keberadaan lumbung desa belum dapat menyerap marketable surplus, sehingga dapat dinyatakan belum dapat digunakan sebagai cadangan pangan masyarakat dan membantu mengamankan harga gabah.

Terkait dengan pemberdayaan kelembagaan lumbung pangan masyarakat, pemerintah mengimplementasikan program aksi pemantapan ketahanan pangan, yang dimulai pada tahun 2002 di 13 propinsi yang melibatkan 57 kabupaten dengan melibatkan kelompok lumbung. Pada tahun 2003, diperluas mencakup 22 propinsi, 96 kabupaten dan 330 kelompok lumbung (Jayawinata, 2003). 
Program ini berupa pemberian pinjaman untuk penguatan modal usaha dengan nama BPLM (Bantuan Pinjaman Langsung Masyarakat). Tujuan BPLM adalah:

- Penguatan modal usaha

- Penumbuhan kegiatan ekonomi

- Peningkatan kewirausahaan

Pelaksanaan program oleh pemerintah dilakukan dengan lima tahap yaitu:

- Seleksi calon petani dan calon lokasi secara partisipatif

- Penyaluran dana

- Proses pemberdayaan kelembagaan kelompok tani secara terprogram

- Pencairan dana oleh petani berdasar perencanaan partisipatif

- Penggunaan dana oleh kelompok sesuai perencanaan dengan menerapkan prinsip keberlanjutan

Besar dana pinjaman BPLM adalah Rp 25 juta per lumbung. Penggunaan dana tersebut di lapangan, kelompok diberi keleluasaan untuk menentukan prioritas jenis usaha yang akan dilakukan, seperti untuk simpan pinjam, pembelian saprodi, atau proses penanganan pascapanen.

Pemberian BPLM disertai dengan kegiatan pendampingan dan pembinaan oleh instansi terkait. Pendampingan dilakukan untuk memfasilitasi proses pengambilan keputusan berbagai kegiatan yang terkait dengan kebutuhan anggota, diarahkan kepada kemampuan dalam meningkataan pendapatan, melaksanakan usaha berskala bisnis, serta mengembangkan perencanaan dan pelaksanaan kegiatan yang partisipatif. Pembinaan dilakukan dalam perencanaan usaha kelompok, prosedur permohonan bantuan, proses pengadministrasian/pembukuan pengelolaan dana, cara mengangsur bunga, pembayaran angsuran dan pelunasan pinjaman.

Dewasa ini keadaan dihadapkan pada kerawanan pangan akibat kenaikan harga pangan atau bencana alam, maka kelembagaan lumbung pangan masyarakat ini menjadi urgent untuk ditumbuhkan kembali atau dikembangkan menuju pada terwujudnya ketahanan pangan di tingkat rumah tangga ataupun di tingkat lokal, sehingga memperkuat ketahanan pangan nasional.

\section{PENUTUP}

Permasalahan sehubungan dengan ketahanan pangan adalah penyediaan, distribusi dan konsumsi pangan. Penyediaan dihadapkan pada semakin terbatas dan menurunnya kapasitas produksi. Distribusi dihadapkan pada permasalahan prasarana dsitribusi darat dan antar pulau, kelembagaan dan keamanan jalur distribusi, serta bervariasinya kapasitas produksi antar wilayah dan antar musim. Permasalahan konsumsi adalah belum terpenuhinya kebutuhan pangan, karena belum tercukupinya konsumsi energi (meskipun konsumsi protein sudah mencukupi), serta konsumsi energi yang sebagian besar dari padi-padian, dan bias ke beras.

Arah kebijakan umum ketahanan pangan adalah mewujudkan kemandirian pangan untuk menjamin ketersediaan dan konsumsi pangan yang cukup, aman, bermutu dan bergizi seimbang pada tingkat rumah tangga, daerah dan nasional sepanjang waktu dan merata melalui pemanfaatan sumber daya dan budaya lokal, teknologi inovatif dan peluang pasar, serta memperkuat ekonomi kerakyatan 
dan mengentaskan dari kemiskinan. Strategi pelaksanaan kebijakan tersebut dilakukan melalui pembangunan ekonomi berbasis pertanian dan pedesaan, serta pemenuhan pangan bagi kelompok masyarakat miskin dan rawan pangan.

Dengan arah kebijakan tersebut, maka ketahanan pangan difokuskan kepada pemberdayaan rumah tangga dan masyarakat agar mampu menolong dirinya sendiri dalam mewujudkan ketahanan pangan dan mengatasi masalah-masalah pangan yang dihadapi. Pemberdayaan ketahanan pangan masyarakat diimplementasikan melalui program Desa Mandiri Pangan yang dimulai pada tahun 2005.

Dalam rangka memupuk cadangan pangan masyarakat, maka perlu untuk menumbuhkan lumbung desa atau meningkatkan fungsi lumbung desa yang telah ada, apalagi bila dilakukan pada desa mandiri pangan yang telah dirintis oleh pemerintah. Keberadaan lumbung pangan diarahkan menuju lumbung desa sebagai sarana untuk pemupukan cadangan pangan masyarakat yang fungsinya adalah mewujudkan ketersediaan, distribusi, dan konsumsi pangan dari waktu ke waktu.

\section{DAFTAR PUSTAKA}

Apriyantono, Anton. 2006. Kebijakan Strategis Pembangunan Ketahanan Pangan Nasional. Naskah Pidato pada Dies Natalis ke XX dan Wisuda Sarjana Univertas Islam Darul Ulum. Lamongan Jawa Timur. 9 Desember 2006.

Apriyantono, Anton. 2007. Arahan Umum. Naskah Pidato pada Rapat Koordinasi Percepatan Pembangunan Pertanian
Wilayah Kalimantan, Banjarmasin, 2728 Februari 2007.

Arifin, Bustanul. 2007. "Strategi dan Kebijakan Sektor Pertanian dalam Mewujudkan Kesejahteraan Petani dan Kedaulatan Pangan". Paper disampaikan pada Seminar Milad ke-9 Partai Keadilan Sejahtera: Membela Ekonomi Rakyat-Ketahanan dan Kemandirian Pangan serta Perumahan yang Layak bagi Rakyat, untuk keberlanjutan Pembangunan Bangsa. Jakarta. 20 April 2007.

Arifin, Bustanul. 2004. Analisis Ekonomi Pertanian Indonesia. Jakarta: Penerbit Buku Kompas.

Badan Ketahanan Pangan Propinsi Jawa Timur. 2005. Pengembangan Desa Mandiri Pangan.

Badan Ketahanan Pangan. 2005. Kebijakan Umum Ketahanan Pangan.

Daerobi, Akhmad, Heri Sulistyo Jati, Tetuko Rawidyo Putro. 2006. "Impact of Agricultural Sector on Poverty Alleviation: Conceptual Framework with Empirical Evidence Pre-Post Crisis (Case Study: Central Java)". Makalah dipresentasikan pada Indonesian Regional Science Association (IRSA) International Seminar, 18-19 Agustus 2006, Malang, Jawa Timur.

Departemen Pertanian-Badan Bimas Ketahanan Pangan-Dewan Ketahanan Pangan. 2002. Kajian Situasi Lumbung Pangan Masyarakat di Propinsi Jabar dan Jateng. Pusat Pengembangan Ketersediaan Pangan.

Jayawinata, Ardi. 2003. Pemberdayaan Lumbung Pangan Masyarakat. Gizi.net.

Krisnamurthi, Bayu. 2006. Mencari Bentuk Politik Ekonomi Pertanian Indonesia. 